\title{
ANALISIS YURIDIS TANGGUNG JAWAB NEGARA TERHADAP DAMPAK RADIASI NUKLIR MENURUT HUKUM INTERNASIONAL (Studi Kasus Radiasi Nuklir Jepang Pasca Gempa Dan Tsunami)
}

\author{
Naek Siregar
}

Dosen Bagian Hukum Internasionl Fakultas Hukum Universitas Lampung

\begin{abstract}
Abstrak
Radiasi nuklir Jepang pasca gempa dan tsunami tahun 2011 telah berdampak buruk bukan hanya bagi Jepang tetapi juga bagi negara lain seperti Korea Selatan. Peristiwa kecelakaan yg menyebabkan radiasi nuklir tersebut terjadi karena dua factor, yaitu factor yang murni sebagai akibat langsung karena gempa bumi danTsunami atau bencana alam, serta factor adanya tindakan operator instalasi nuklir membuang limbah ke laut. Terhadap factor bencana alam, hukum internasional mengatur bahwa Jepang tidak dapat dibebani tanggung jawab, namun terhadap factor perbuatan atau tindakan, Jepang dapat dikenakan tanggung jawab karena telah melanggar ketentuan-ketentuan hukum internasional.
\end{abstract}

Kata Kunci: Tanggung jawab Negara, Radiasi Nuklir, Hukum Internasional

\section{PENDAHULUAN}

Penggunaan tenaga nuklir pada umumnya tidak hanya menimbulkan efek yang bermanfaat dan berguna bagi masyarakat negara penggunanya, tenaga nuklir juga dapat menimbulkan dampak yang sangat buruk bagi makhluk hidup maupun lingkungan apabila dalam pengguna- annya terjadi kecerobohan.atau tidak hati-hati. Salah satu contoh nyata dampak buruk yang timbul sebagai akibat penyalahgunaan dan kecerobohan manusia adalah peristiwa kecelakaan pada Pembanmgkit Listrik Tenaga Nuklir(PLTN) Chernobyl yang terletak di Ukraina, dima- na reaktor nuklir tersebut meledak pada tanggal 26 April 1986 dan menimbulkan radiasi nuklir yang sangat berbahaya. Laporan WHO menyebutkan bahwa bahwa peristiwa kecelakaan tersebut telah menimbulkan sangat banyak korban jiwa meninggal seketika dan yang mening- gal bertahun-tahun sesudahnya akibat radiasi nuklir tersebut, juga menimbulkan banyak penyakit, di antaranya kanker. ${ }^{1}$

Peristiwa kecelakaan nuklir yang telah berdampak bukan hanya di negara yang bersangkutan melainkan juga pada negara tetangga ,telah memicu pembicaraan atau polemic di seluruh dunia tentang kepantasan skema pertanggungjawaban nuklir yang telah ada. Dalam periode Tahun 1988 sampai 2004 telah berlangsung perundinganperundingan untuk mempertimbang kan pengalaman Chernobyl dan untuk memperkuat pengaturan hukum internasional tentang penggunaan nuklir.

Peristiwa Chernobyl juga telah mendorong suatu tindakan segera yang berkelanjutan dan

1 Inilah Dampak Radiasi Nuklir Bagi Manusia, diakses dari: http://news.okezone.com/read/2011/03/16/3 37/435349/ inilah -dampak-radiasi nuklirbagi manusia, pada 29 Nopember 2011. 
komprehensif dari masyarakat internasional yang menghasilkan sejumlah instrumen internasional baru yang ditujukan untuk menghindari atau mengatasi kelemahan rezim hukum internasional pra- 1986 yang terbukti tidak berjalan efektif. ${ }^{2}$

Penggunaan tenaga nuklir juga menuntut sebuah tanggungjawab yang besar,yakni keselama-tan dan keamanan yang tinggi dan kerawanan digunakan untuk tujuan terorrisme. Untuk mencegah terjadinya penyimpangan penggunaan tenaga nuklir, masyarakat internasional mendirikan suatu badan internasional di bawah naungan Perserikatan Bangsa-Bangsa (PBB), yakni Badan Tenaga Atom Internasional(International Atomic Energy Agency/IAEA).

IAEA merupakan sebuah organisasi independent yang didirikan pada tanggal 29 Juli 1957 bermarkas di Wina Austria dengan tujuan mempromosikan penggunaan energy nuklir secara damai serta untuk menangkal penggunaannya untuk keperluan militer. ${ }^{3}$

Kasus terbaru mengenai pencemaran nuklir yang terjadi barubaru ini adalah kebocoran pada Bangunan Pembangkit Listrik Tenaga Nuklir (PLTN) Fukushima Daiichi di Sendai, Jepang. Kebocoran ini berawal dari terjadinya gempa berkekuatan 9,0

2 Perjanjian Ketenaganukliran Pada Penggunaan Nuklir Tujuan Damai,diakses dari: Http//sainsindonesia.wordpress.com/ 2010/10/06/perjanjian-internasional-kete naganukliran-pada-penggunaan-tenaganuklir-untuk-tujuan-damai/, pada 29 Nopemeber 2011

${ }^{3}$ Badan Tenaga Atom Internasional, diakses dari: $\quad$ http://id.wikipedia.org/wiki/Badan Tenaga Atom Internasional. Pada 30 Nopember 2011.
Skala Richter disusul gelom- bang Tsunami setinggi 10 meter.

Kebocoran reaktor nuklir ini menyebabkan bencana baru yaitu radiasi nuklir yang sangat mengkhawatirkan bukan hanya bagi masyarakat Jepang namun juga bagi negara-negara tetangganya. ${ }^{4}$ Badan Keselamatan Nuklir yang menangani masalah nuklir di Jepang mengatakan bahwa radiasi nukir yang diakibatkan gempa dan tsunami itu telah menyebabkan kerugian materil yang sangat besar yakni Rp 2.068 Triliun. ${ }^{5}$

Radiasi nuklir tersebut juga menyebabkan dampak buruk bagi lingkungan, terutama lingkungan laut. Informasi terakhir menyebutkan bahwa laut Pasifik yang menjadi salah satu batas wilayah dengan Korea Selatan sudah tercemar radiasi nuklir. Pencemaran itu diduga kuat terjadi ketika para petugas pemadam kebakaran dan para teknisi nuklir Jepang akhirnya menggunakan air laut untuk mendinginkan reaktor. Korea Selatan telah menyampaikan protes atas keputusan Jepang membuang air radioaktif ke laut dalam upaya menstabilkan PLTN Fukushima. Adapun volume air radiaktif yang dibuang ke laut Pasifik mencapai lebih dari 10.000 ton dengan level radiasi 500 kali di atas normal. Seorang pejabat Korea Selatan mengatakan, "bahwa jarak antara kedua negara yang dekat

\footnotetext{
4 Gempa,Tsunami, dan Radiasi Nuklir Jepang, diakses dari http://www.bodhidharma.or.id/beritabodhi/3 7-news/105-gempa-tsunami-radiasi nuklirjepang.html. Pada 30 Nopember 2011.

${ }_{5}$ Total Kerugian Jepang Akibat Gempa dan Tsunami, diakses dari: http//news.aribicara.com/3011/03/21/total kerugian Jepang akibat gempa tsunami-capai 235 milliar -dolar. Diakses pada 30 Nopember 2011.
} 
membuat kami khawatir dengan air radiaktif yang di buang ke laut."6

Kebocoran reaktor nuklir yang sangat besar dapat menimbulkan kerugian yang besar bagi banyak pihak termasuk bagi negara lain, dimana hal ini sekaligus akan memunculkan suatu pertanggungjawaban negara.

Hukum internasional mengatur bahwa suatu negara dapat diminta pertanggungjawabannya apabila negara tersebut melakukan suatu perbuatan ataupun kelalaian yang melahirkan pelanggaran terhadap suatu kewajiban internasional, baik yang lahir dari suatu perjanjian internasional maupun dari sumber hukum internasional lainnya. ${ }^{7}$

Berdasarkan azas hukum internasional,pertanggungjawaban

dalam hal kecelakaan nuklir merupakan pertanggungjawaban absolute. Ini berarti jika terjadi kecelakaan nuklir maka operator bertanggungjawab mutlak, sedangkan pihak korban atau pihak ketiga dibebaskan dari tanggung jawab. Hal ini sesuai dengan prinsip yang diatur dalam Konvensi Paris 1960, Convention on Third Party Liability in The Field of Nuclear Energy, yang kermudian di lengkapi dengan Konvensi Brussel 1963 plus Protokol 1982, dan Konvensi Wina 1963, Convention on Civil Liability for Nuclear Damage.

Penggunaan tenaga nuklir yang pada umumnya rawan kecelakaan memunculkan pertanyaan bagaimanakah tanggung jawab suatu

6 Air Laut Jepang Tercemar Radiasi Nuklir,diakses dari : http://niponk, blogspot.com/2011/0. pada 30 Nopember 2011.

7 Tanggung Jawab Negara,Pengantar Hukum Internasional,edisi ke SepuluhTerjemahan. J.G. Starke,Sinar Grafika,Jakarta 2003. negara yang memanfaatkan tenaga nuklir untuk kepentingan negaranya dengan maksud atau tujuan damai? Penelitian ini hendak menjawab pertanyaan bagaimanakah ketentuan hukum internasional yang mengatur tentang pemanfaatan nuklir untuk tujuan damai dan tanggung jawab negara, dan bagaimanakah tanggung jawab negara Jepang terhadap dampak radiasi nuklir akibat bencana alam dan akibat pembuangan limbah nuklir ke laut?

Berdasarkan masalah yang diuraikan di atas, tujuan penulisan ini adalah menjelaskan tentang ketentuan-ketentuan hukum internasional yang berkaitan dengan pembuangan limbah nuklir; menjelaskan tanggung jawab negara Jepang terhadap dampak radiasi nuklir akibat bencana alam dan akibat pembuangan limbah nuklir ke laut.

\section{PEMBAHASAN}

\subsection{Ketentuan Internasional yang terkait dengan Pemanfaatan Nuklir Untuk Tujuan Damai dan Tanggung jawab Negara}

\subsubsection{Convention on Nuclear Safety (Konvensi Tentang Keselamatan Nuklir)}

Konvensi keselamatan nuklir pada dasarnya akan memberi jaminan perlindungan bagi pekerja, masyarakat dan lingkungan hidup. Berdasarkan ketentuan Pasal 1, tujuan Konvensi adalah :

(1) Untuk mencapai dan
mempertahankan tingkat
keselamatan nuklir yang tinggi
di seluruh dunia melalui
peningkatan langkah-langkah
atau kegiatan yang dilakukan 
secara nasional dan kerjasama internasional;

(2) Untuk membangun dan memelihara pertahanan yang efektif dari instalasi nuklir terhadap bahaya radiologis, dan untuk melindungi individu, masyarakat dan lingkungan dari bahaya radiasi nuklir;

(3) Untuk mencegah terjadinya kecelakaan nuklir yang menyebabkan bahaya radiologis tersebut.

Pasal 6, mengatur bahwa setiap pihak wajib mengambil langkahlangkah tepat untuk memastikan bahwa keselamatan instalasi nuklir yang ada harus harus ditinjau ulang secepat mungkin agar sesuai dengan ketentuan Konvensi ini. Jika perbaikan tersebut tidak dipenuhi, maka harus direncanakan untuk menutup instalasi nuklir tersebut secepat mungkin.

Pasal 10 Konvensi tentang keselamatan nuklir juga mengatur bahwa setiap pihak wajib mengambil langkah-langkah tepat untuk memastikan bahwa semua organisasi yang terlibat dalam kegiatana yang berhubungan langsung dengan instalasi nuklir harus menetapkan kebijakan yang lebih mengutamakan keselamatan nuklir.

Pada bagian lain juga diatur bahwa setiap pihak dalam Konvensi ini harus mengambil langkah yang tepat untuk memastikan tersedianya sumber daya keuangan yang memadai untuk mendukung keselamatan setiap instalasi nuklir dan memastikan tersedianya staf yang berkualitas dengan pendidikan yang tepat, pelatihan yang tepat dan berkesinambungan. Setiap pihak harus mengambil langkah yang tepat untuk memastikan bahwa pada waktu pengoperasian instalasi nuklir, maka paparan radiasi kepada pekerja dan masyarakat harus dijaga serendah mungkin dan setiap pihak harus memastikan bahwa tidak ada individu yang terkena radiasi nuklir yang melebihi dosis normal. Hal ini sesuai dengan ketentuan Pasal 15 Convention on Nuclear Safety, yang berbunyi:

"Each Contracting Party shall take the appropriate steps to ensure that in all operational satates the radiation esposure to the workers and the public cauased by a nuclear installation shall be kept as low as reasonably achieveable prescribed national dose limits".

Uraian di atas menunjukkan bahwa Konvensi tentang Keselamatan Nuklir ini sangat penting peranannya karena konvensi ini bertujuan untuk melibatkan secara legal partisipasi dari negara-negara yang mengoperasikan PLTN untuk menjaga keselamatan tingkat tinggi dengan cara menetapkan standarstandar internasional keselamatan nuklir yang harus dianut negaranegara, khususnya dalam hal pemanfaatan nuklir untuk tujuan damai.

\subsubsection{The Convention on The Physical Protection of Nuclear Material (Konvensi Tentang Perlindungan Fisik Bahan Nuklir)}

Konvensi ini mulai berlaku efektif pada 8 Pebruari 1987 dan Indonesia telah menandatangani Konvensi ini pada tanggal 3 Juli 1986, serta meratifikasinya pada 5 Nopember $1986 .{ }^{8}$ Pasal 2 mengatur

8
Ketenaganukliranjian diakses dari:


bahwa Konvensi ini berlaku untuk bahan nuklir yang digunakan untuk tujuan damai ketika masih dalam tahap pengangkutan atau perjalanan atau masih dalam proses penyimpanan di dalam negeri. Pasal 3 mengatur bahwa setiap negara harus mengambil langkah yang tepat dalam kerangka hukum nasional dan sesuai dengan hukum internasional untuk menjamin bahwa selama bahan nuklir diangkut melalui wilayahnya,atau pada kapal atau pesawat udara dibawah yurisdiksinya harus dilindungi.

Selanjutnya untuk melindungi fisik bahan nuklir maka konvensi ini mengatur beberapa kewajiban para pihak sebagaimana diatur dalam Pasal 4:

a. Setiap negara tidak akan mengekspor atau mengijinkan ekspor bahan nuklir kecuali negara tersebut telah menerima jaminan bahwa bahan nuklir tersebut akan dilindungi selama proses pengangkuta;

b. Setiap negara tidak akan mengimpor atau mengijinkan impor bahan nuklir kecuali negara pihak telah menerima jaminan bahwa materi tersebut akan dilindungi seama proses pengankutan;

c. Suatu negara tidak akan mengijinkan bahan nuklir transit di wilayahnya atau melalui bandara atau pelabuhan di wilayahnya kecuali negara tersebuttelah menerima jaminan bahwa bahan nuklir tersebut akan dilindungi selama proses pengangkutan;

http://sainsindonesia.wordpres.com/2010/10/ 06/perjanjian internasionalketenaganukliran-pada penggunaan-nukirtujuan damai/. Pada 20 Nopember 2011. d. Setiap negara wajib menerapkan dalam kerangka hukum nasional perlindungan fisik bahan nuklir, yang diangkut dari wilayah suatu negara ke wilayah negara lain yang melalui perairan internasional atau wilayah udara yang sama.

Ketentuaan-ketentuan di atas menunjukkan bahwa Konvensi ini mempunyai tujuan dan peranan yang sangat mendukung pemanfaatan tenaga nuklir untuk tujuan damai karena Konvensi ini menghendaki adanya tingkat keselamatan nuklir yang tinggi di seluruh dunia terutama dalam pemanfaatan tenaga nuklir untuk tujuan damai.

\subsubsection{Convention The Responsibility of States for Internationally Wrongful Acts (Konvensi Tentang Tanggung Jawab Negara Karena Perbuatan yang dipersalahkan menurut Hukum Internasional}

Keharusan suatu negara untuk bertanggung jawab terhadap tindakan-tindakannya yang secara internasional tidak sah, secara tegas diatur dalam Pasal 1 Convention The Resposibility of States for Internationally Wrongful Acts 2001, yaitu: "Every Internationally wrongful act of State entails the international responsibility of that State".

Dalam bab V Konvensi ini diatur pula beberapa hal tentang pembenaran terhadap pelanggaran internasional, yakni:

a. Persetujuan, yakni persetujuan yang sah oleh suatu negara terhadap tindakan dari negara lain yang bertentangan namun tindakan tersebut masih dalam 
batas-batas persetujuan (Pasal 20);

b. Pembelaan diri. Suatu negara diijinkan bertindak dalam caracara yang bertentangan dengan kewajiban internasional dengan tujuan membela diri, sebagaimana dinyatakan dalam Piagam PBB(Pasal 21);

c. Tindakan-Tindakan

Balasan,yakni tindakan balasan yang atas pelanggaran yang dilakukan oleh negara lain dengan cara pembalasanpembalasan yang sah dan diperkenankan dalam hukum internasional dan tidak melibatkan angkatan bersenjata (Pasal 22);

d. Force majeure. Suatu negara diijinkan bertindak dalam cara yang bertentangan dengan kewajiban internasional jika perbuatan itu karena force majeure, yaitu terjadinya situasi yang benar-benar di luar kemampuan,atau suatu peristiwa yang tak terduga atau di luar kendali Negara (Pasal 23);

e. Distress atau Kesulitan. Suatu negara diijnkan bertindak dalam cara yang bertentangan dengan kewajiban internasional jika dalam situasi dimana negara pelaku tidak memiliki cara lain yang lebih baik dalam upayanya menyelamatkan hidupnya atau orang-orang yang berada dalam tanggung jawabnya(Pasal 24);

f. Necessity atau Kebutuhan. Kebutuhan merupakan pembenaran terhadap pelanggaran internasional oleh suatu negara hanya apabila tindakan tersebut:

- adalah satu-satunya cara bagi negara untuk melindungi kepentingannya dari bahaya yang serius, dan

- tidak secara luas merusak kepentingan dari negara tersebut.

Terjadinya radiasi nuklir Jepang baru-baru ini disebabkan terjadinya bencana alam yakni adanya gempa bumi yang berkekuatan tinggi yang disusul dengan adanya Tsunami yang mengakibatkan terjadinya kebocoran pada instalasi nuklir. Peristiwa terjadinya gempa bumi dan Tsunami dikategorikan sebagai peristiwa yang di luar kemampuan atau suatu peristiwa yang tak terduga dan di luar kendali negara Jepang.

\subsubsection{Convention on Third Party Liability in The Field of Nuclear Energy (Konvensi tentang Kewajiban Pihak Ketiga di Bidang Energi Nuklir)}

Pasal 3 Convention on Third Party Liabillity in The Field of Nuclear Energy mengatur bahwa operator dari sebuah instalasi nuklir bertanggung jawab untuk:

1. kerusakan atau hilangnya kehidupan dari setiap orang, dan

2. kerusakan atau kehilangan harta lainnya.

Selanjutnya dalam Pasal 6 huruf (b) disebutkan bahwa hak atas kompensasi atas kerusakan yang disebabkan oleh kecelakaan nuklir hanya dapat dibebankan terhadap operator yang bertanggung jawab atas kerusakan sesuai dengan Konvensi ini. Ketentuan ini menegaskan bahwa pihak yang bertanggung jawab apabila terjadi kerusakan atau hilangnya kehidupan seseorang maupun kerusakan atau hilangnya harta lainnya adalah pihak 
yang mengoperasikan(operator) instalasi nuklir. Jadi apabila Jepang sebagai operator telah dinyatakan bertanggung jawab atas kecelakaan nuklir yang terjadi,maka negara Jepang harus bertanggung jawab untuk kerusakan atau hilangnya kehidupan dari setiap orang dan kerusakan atau hilangnya harta lainnya.

\subsubsection{Vienna Convention on Civil Liability for Nuclear Damage (Konvensi Wina Tentang Tanggung Jawab Sipil Untuk Kecelakaan Nuklir)}

Pasal 2 Konvensi ini mengatur bahwa operator dari sebuah instalasi nuklir bertanggung jawab atas kerusakan nuklir tersebut yang disebabkan oleh kecelakaan nuklir: a. di instalasi nuklirnya, atau b. melibatkan bahan nuklir yang datang dari atau berasal dari instalasi nuklir, dan c. melibatkan bahan nuklir yang dikirim ke instalasi nuklir. Kecelakaan nuklir di Jepang adalah peristiwa kecelakaan yang terjadi di instalasi nuklirnya dan melibatkan bahan nuklirnya dan melibatkan bahan nuklir yang berasal dari instalasi nuklir tersebut pula.

Selanjutnya Pasal 4 ayat (1) mengatur bahwa tanggung jawab operator untuk kerusakan nuklir di bawah Konvensi ini harus mutlak. Sedangkan Pasal 4 ayat(3) butir a dan $b$, mengatakan bahwa tidak ada kewajiban berdasarkan Konvensi ini melimpahkan tanggung jawab terhadap operator untuk atau oleh kecelakaan nuklir yang disebabkan secara langsung oleh kecelakaan nuklir yang disebabkan antara lain oleh konflik bersenjata, permusuhan, perang sipil atau pemberontakan, demikian juga dengan kecelakaan nuklir oleh bencana alam yang luar biasa besarnya.

Mengingat kecelakaan nuklir di Jepang terjadi di instalasi nuklirnya dan melibatkan bahan nuklir yang berasal dari instalasi nuklir tersebut pula, maka sesuai dengan Konvensi Wina tentang Tnggung Jawab Sipil Untuk Kecelakaan Nuklir, Jepang harus bertanggung jawab dan sifatnya mutlak. Namun jika Jepang dapat membuktikan bahwa radiasi tersebut disebabkan oeh bencana alam, maka Jepang dapat terbebas dari tanggung jawab tersebut.

\subsection{Tanggung Jawab Negara Jepang Terhadap Radiasi Nuklir}

Permasalahannya adalah dapatkah negara Jepang dimintai pertanggungjawaban akibat kerugian yang ditimbulkan oleh radiasi nuklir yang terjadi di wilayahnya? Untuk menjawab permasalahan tersebut maka terlebih dahulu kita mengidentifikasi peristiwa apa sesungguhnya yang mengakibatkan terjadinya radiasi nuklir di Jepang.

Penelitian di lapangan menunjukkan terdapat dua peristiwa yang mengakibatkan terjadinya radiasi nuklir yakni bencana alam dan pembuangan limbah nuklir ke laut dimana masing-masing peristiwa tersebut melahirkan akibat hukum yang berbeda.

\subsubsection{Tanggung Jawab Negara Jepang Terhadap Radiasi Nuklir Akibat Bencana Alam}

Berdasarkan $r$ hukum
internasional suatu negara ber-
tanggungjawab bilamana suatu
perbuatan atau kelalaian yang dapat
dipertautkan kepadanya melahirkan


pelanggaran terhadap suatu kewajiban internasional. ${ }^{9}$ Berikut ini penulis akan menganalisis apakh unsure-unsur tersebut dapat terpenuhi dalam peristiwa radiasi nuklir yang terjadi di Jepang barubaru ini.

1. Ada perbuatan atau kelalaian yang dapat dipertautkan (imputable) kepada suatu negara; Pada peristiwa radiasi nuklir tersebut tidak terjadi suatu perbuatan atau kelalaian yang dapat dipertautkan kepada negara Jepang karena peristiwa tersebut murni disebabkan bencana alam.

2. Perbuatan atau kelalaian itu merupakan suatu pelanggaran terhadap suatu kewajiban internasional.

Karena peristiwa radiasi nuklir di atas bukan merupakan suatu perbuatan manusia maupun kelalaian maka tidak perlu dibuktikan apakah peristiwa tersebut merupakan pelanggaran terhadap suatu kewajiban internasional.

$$
\text { Berdasarkan Konvensi Wina }
$$
tentang Tanggung Jawab Sipil Akibat Kecelakaan Nuklir, maka operator tidak bertanggung jawab atas kerusakan nuklir yang disebabkan secara langsung oleh bencana alam yang luar biasa. Hal ini secara tegas diatur di dalam artikel 4 ayat (3) butir b. Jadi berdasarkan kenyataan tersebut Jepang tidak dapat dibebankan tanggung jawab untuk semua kerugian yang diakibatkan oleh radiasi nuklir tersebut karena radiasi tersebut murni disebabkan secara langsung oleh

\footnotetext{
9 Dikutip dalam Malcom N.Shaw,International law, hal 542 oleh Jawahir Thontowi dan Pranoto Iskandar dalam Hukum Internasional Kontemporer, 2006.
}

bencana alam, dan bukan oleh suatu perbuatan maupun kelalaian negara.

\subsubsection{Tanggung Jawab Negara Jepang Terhadap Radiasi Nuklir Akibat Pembuangan Limbah Nuklir Ke Laut}

Tindakan Jepang yang dengan sengaja telah membuang air radioaktif ke laut Pasifik mengakibatkan negara tersebut memikul tanggung jawab. Beberapa ketentuan internasional yang dapat dikaitkan dengan tindakan Jepang membuang air radioaktif ke laut di antaranya adalah :

1. The Joint Convention on The Safety of Spent Fuel Management and the Safety of Radioactive Waste Management (Konvensi Gabungan Tentang Keselamatan Pengelolaan Bahan Bakar Bekas dan Keselamatan Pengelolaan Limbah Radioactive). Pasal 11 mengatur bahwa setiap pihak harus mengambil langkahlangkah yang tepat untuk memastikan bahwa proses atau tahapan pengelolaan bahan radioaktif memberikan perlindungan yang memadai terhadap masyarakat dan lingkungan terhadap bahaya radiologis dan bahaya lain. Berdasarkan Konvensi di atas maka tindakan Jepang membuang limbah radioaktif ke laut yang menyebabkan laut Pasifik tercemar radiasi nuklir dan telah mengakibatkan 17 orang awak kapal induk Angkatan Laut Amerika Serikat terkontaminasi radiasi nuklir, telah melanggar ketentuan hukum internasional yang ada.

2. Convention on The Prevention of Marine Pollution by Dumping of 
Wastes and Other Matter (Konvensi tentang Pencegahan Polusi Laut oleh Pembuangan Limbah dan Bahan Lainnya). Pasal 1 Konvensi ini mengatur bahwa para pihak dalam Konvensi ini wajib secara individual maupun kolektif mempromosikan penanganan yang efektif untuk semua sumber pencemaran lingkungan laut, dan berjanji mengambil langkahlangkah praktis untuk mencegah pencemaran laut oleh pembuangan limbah dan materi lain yang dapat membahayakan kesehatan manusia, sumber daya alam dan kehidupan laut. Jadi tindakan Jepang membuang limbah radioaktif ke laut sudah bertentangan dengan kewajiban para pihak yang ada dalam Konvensi ini.

3. Basel Convention on The Control of Transboundary Movements of Hazardous Wastes and Their Disposal (Konvensi Basel tentang Pengawasan Perpindahan Limbah Berbahaya Yang Melintasi Batas Negara dan Pembuangan Limbah Berbahaya).

Tindakan Jepang yang telah membuang limbah radioaktif ke laut juga telah melanggar ketentuan Pasal 4 ayat (7) Konvensi Basel, dimana dalam ketentuan ini dikatakan bahwa setiap pihak wajib:

a. Melarang semua orang di bawah yurisdiksinya memindahkan atau membuang limbah berbahaya atau limbah yang lain kecuali orang-orang tersebut resmi diperbolehkan untuk melakukan kegiatan tersebut;

b. Mewajibkan setiap limbah berbahaya dan limbah lainnya yang akan melintasi batas negara dikemas, diberi label, dan diangkut sesuai dengan peraturan internasional yang berlaku;

c. Mewajibkan bahwa limbah berbahya dan limbah lainnya disertai dengan dokumen dari tempat awal dimana limbah tersebut berada sampai ke titik pembuangan.

Fakta menunjukkan bahwa pembuangan limbah radioaktif yang dilakukan oleh Jepang tidak memenuhi satupun point yang ada dalam ketentuan Pasal 4 ayat (7) Konvensi Basel tersebut. Bahkan Pembuangan limbah tersebut juga bertentangan dengan ketentuan yang ada di dalam Pasal 9 Convention on The Control of Transboundary Movements of Hazardous Wastes and Their Disposal, karena tidak terlebih dahulu memberitahu atau tanpa persetujuan dari negara-negara yang mungkin akan terkena dampak dari pembuangan limbah tersebut.

Pasal 4 Articles on The Responsibility of States for Internationally Wrongful Acts 2001 mengatur bahwa tindakan yang dapat dilimpahkan kepada negara adalah:

a. Tindakan organ negara dalam kapasitas resmi. Organ negara dalam kapasitas resmi yang dimaksud di sini adalah lembaga atau pejabat - pejabat negara yang berdasarkan Undang-Undang terdapat di dalam hukum nasional suatu negara. Pembuangan air radioaktif ke laut Pasifik merupakan kebijakan pemerintah Jepang dan dilakukan oleh Badan Keselamatan Nuklir bersama Operator PLTN. ${ }^{10}$

10 Jepang Buang Air Radioaktif ke Laut. Diakses dari: 
b. Tindakan kesatuan (entity) atau daerah yang ada dalam negara, atau tindakan kesatuan di luar struktur formal pemerintah pusat atau pemerintah daerah .

Berdasarkan kenyataan tersebut, negara Jepang dapat dibebani tanggung jawab secara internasional atas kerugian-kerugian yang ditimbulkan oleh radiasi nuklir karena kriteria-kriteria agar suatu negara dapat dilimpahkan tanggung jawab sudah terpenuhi, yakni adanya tindakan atau kelalaian yang melanggar hukum internasional dan adanya keterlibatan organ negara dalam kapasitas resmi di dalam pembuangan air radioaktif ke laut Pasifik.

\section{PENUTUP}

Berdasarkan pembahasan dapat disimpulkan bahwa sejauh menyangkut bencana alam Jepang tidak dapat dibebankan tanggung jawab atas kerugian yang timbul karena radiasi. Akan tetapi atas kebijakan pemerintah Jepang yang mengijinkan pembuangan limbah nuklir ke laut, Jepang dapat diminta pertanggungjawaban.

Salah satu bentuk tanggung jawab yang bisa dilakukan oeh Jepang adalah dengan memberikan ganti rugi. Adapun bentuk-bentuk ganti rugi, yaitu: 1. Restitusi; 2. Kompensasi; $3 . \quad$ Pemuasan (Satisfaction). Restitusi adalah membangun kembali situasi seperti semula tindakan melanggar hukum internasional dilakukan. Kompensasi adalah ganti rugi terhadap kerusakan yang disebabkan tindakan melanggar

http://makassar.tribunnews.com/2011/04/05, pada 1 Desember 2011. hukum internasional, dan kompensasi tersebut harus mencakup kerusakan financial termasuk kemungkinan hilangnya keuntungan.

Pemuasan atau Satisfaction adalah kewajiban untuk memberikan kepuasan bagi negara yang dirugikan dimana restitusi dan kompensasi tidak dapat memperbaikinya. Pemuasan dapat berupa pengakuan tentang pelanggaran, ungkapan penyesalan, dan permintaan maaf secara formal atau dengan cara lain.

Sikap yang diambil oleh pemerintah Jepang dalam pemenuhan kewajiban pertanggungjawabannya adalah dengan memberikan kompensasi dan pemuasan, yaitu melalui undangundang untuk membentuk badan yang didukung negara yang akan membayar ganti rugi kerusakan senilai puluhan miliar dolar bagi korban bencana nuklir Fukushima. Berdasarkan UU tersebut, operator Fukushima Tokyo Electric Power Company (TEPCO) dan perusahaan tenaga atom lain juga akan membayar dana itu yang akan dibagikan kepada korban sebagai kompensasi. ${ }^{11}$ Pemerintah Jepang juga memberikan pemuasan (satisfaction) yang dilakukan dengan permintaan maaf oleh Pejabat Jepang kepada semua korban atas pembuangan 11.500 ton air radioaktif ke laut Pasifik. ${ }^{12}$

\footnotetext{
11 Jepang membentuk Badan Pembayaran Ganti rugi Korban Nuklir, diakses dari: http://www.antaranews.com/berita/27009 pada 18 September 2011

12 Jepang Resmi Minta Maaf. Diakses dari: http//www.wartanews.com/read/Internationa 1/d97e2f89-a409, pada 31 September 2011
} 


\section{DAFTAR PUSTAKA}

Adibaskoro,Tito. 2008. Energi Nuklir dan Alternatif Pembangkit Listrik di Indonesia, Jakarta: Raja Grafindo Persada.

Akhadi, Mukhlis. 1997. Pengantar Teknologi Nuklir. Jakarta: PT. Rineka Cipta.

Departemen Pendidikan Nasional dan Kebudayaan.1989. Kamus Besar Bahasa Indonesia. Jakarta : Balai Pustaka.

Starke, J.G. 2003. Pengantar Hukum Internasional. Jakarta: Sinar Grafika.

Thantowi, Jawahir dan Pranoto Iskandar.Hukum Internasional Kontemporer. 2006. Bandung: Refika Aditama.

Wallace, M Rebecca.1993. HUkum Internasional. Semarang: IKIP Semarang Press.

Undang-Undang RI Nomor 10 Tahun $1997 \quad$ Tentang Ketenaganukliran.

Convention on Nuclear Safety (Konvensi tentang Keselamatan Nuklir).

Convention on The Physical Protection of Nuclear Material(Konvensi Tentang Perlindungan Fisik Bahan Nuklir).

The Resposibility of States for Internationally Wrongful Acts.

Konvensi Wina tentang Tanggung Jawab Sipil Akibat Kecelakaan Nuklir.

\section{Website}

http://News.okezone.com. Inilah Dampak Radiasi Nuklir Bagi Manusia.

http://id.wikipedia.org/wiki. Badan Tenaga Atom Internasional

http://www.bodhidharma.or.id/berita bodhi. Gempa, Tsunami, dan Radiasi Nuklir Jepang

http://sainindonesia.wordpress.com. Perjanjian Ketenaganukliran Pada Penggunaan Nuklir untuk Tujuan Damai.

http//:news.aribicara.com. Total Kerugian Jepang Akibat Gempa dan Tsunami

http//:niponk.blogspot.com. Air Laut Tercemar Radiasi Nuklir. 